\title{
REINTERPRETASI TERHADAP PEMAHAMAN HADITS-HADITS TENTANG GENDER DALAM PERSPEKTIF FIQH AL-HADITS
}

\author{
Zailani, ${ }^{1}$ Kaizal Bay, ${ }^{1}$ dan Sri Chalida ${ }^{2}$ \\ ${ }^{1}$ UIN Sultan Syarif Kasim Riau \\ ${ }^{2}$ IAIN Imam Bonjol Padang \\ zailani@uin-suska.ac.id
}

\begin{abstract}
There are a lot of hadiths that influenced certain circumstances, especially those "degrading" degrees of women. If the hadiths are textually practiced, there would certainly be an impact on human-right violations. If broken, it will also affect the person's faith in applying the traditions of Prophet SAW in his life. This issue certainly needs the best solution in understanding these hadiths. It is unneglectable to avoid that women harassment are still happening today. Everyone witnesses that so many women lost their rights, both as a human being, such as subordinated to its shortcomings, but also as citizens, such as loss of right to be a leader. The women with this particular plight are the result of men's behavior who stand on religious arguments (especially hadith) that put women as "humbled" and even simply as the creature that confined to live in walls of house, which is just back and forth between the kitchen, wells and mattresses. Reinterpretation of Islamic concepts on the position of women should be provided in order to give opportunity to the present women as highly dynamic, courteous, and beneficial for religion and society. We all believe that Prophet Muhammad SAW was the great personal who respected and uphold the honor of women. This is the gap between the will of the Prophet SAW with the understanding of Muslim believers about the hadiths of the Prophet SAW.
\end{abstract}

Keywords: Reinterpretation, Hadith, and Gender

\begin{abstract}
Abstrak
Hadits-hadits yang dipengaruhi oleh situasi dan kondisi tertentu sangat banyak, khususnya hadits-hadits yang "merendahkan" derajat perempuan, sehingga apabila diamalkan secara tekstual tentu akan berdampak pada pelanggaran hak asasi manusia, begitupun jika dilanggar tentu juga akan berpengaruh terhadap keimanan seseorang dalam mengaplikasikan sunnah-sunnah Rasul SAW dalam kehidupannya. Persoalan ini tentu harus dicari solusi terbaik dalam memahami hadits-hadits tersebut. Sulit dipungkiri bahwa pelecehan terhadap perempuan masih dirasakan sampai saat sekarang, sehingga banyak perempuan yang hilang haknya, baik sebagai manusia,seperti dinomorduakan karena kekurangan yang dimilikinya, maupun sebagai warga negara, seperti hilangnya hak untuk menjadi pemimpin. Nestapa seorang perempuan lebih banyak disebabkan oleh perilaku laki-laki yang berdiri di atas dalil-dalil agama (khususnya hadits) yang menempatkan perempuan sebagai makhluk yang "direndahkan" bahkan hanya sebagai makhluk yang terkurung dalam dinding rumah, yang hanya bolak balik antara dapur, sumur, dan kasur. Sudah waktunya dilakukan reinterpretasi terhadap konsep-konsep Islam yang lebih memberi
\end{abstract}


peluang menghadirkan seorang perempuan sebagai sosok yang dinamis, sopan, dan bermanfaat bagi agama dan masyarakat. Karena kita juga yakin bahwa Nabi Muhammad SAW merupakan pribadi agung yang sangat menghargai dan menjunjung tinggi kehormatan perempuan. Hal inilah yang menjadi kesenjangan antara kehendak Nabi SAW dengan pemahaman umat tentang hadits-hadits dari Nabi SAW.

Kata kunci: Reinterpretasi, Hadits, dan Gender

\section{Pendahuluan}

Kajian hadits dengan memfokuskan pada kritik matan sebenarnya bukanlah persoalan baru dalam sejarah Islam. Pada fase-fase awal Islam, para sahabat tidak lama setelah Nabi wafat, yang dimotori oleh 'Umar bin al-Khattab (w. $23 \mathrm{H}$ ) dan 'Usman bin Affan (w. $35 \mathrm{H}$ ), telah melakukan kontekstualisasi hadits. 'Umar misalnya, melakukan pengubahan sistem pembagian harta rampasan perang, tidak seperti yang dipraktikkan pada masa Nabi dan Abu Bakar al-Siddiq (w. 13 H). Begitu pula 'Usman yang menetapkan penggunaan bahasa suku Quraisy sebagai rujukan dalam membuat kodifikasi yang ditetapkan sebagai mushaf standar (mushaf al-imam). Dalam skala individu, kontekstualisasi hadits itu bahkan telah dilakukan sahabat di zaman Nabi sendiri. Buktinya, ketika mengirim utusan ke Bani Quraizah untuk menyelesaikan suatu urusan, Nabi berpesan agar mereka tidak melakukan shalat 'Ashar sebelum sampai di perkampungan salah satu Bani (clan) kaum Yahudi itu. Di tengah perjalanan, karena waktu 'Ashar telah tiba, dan Bani Quraizah telah dekat, sebahagian dari utusan itu melakukan shalat, mereka memahami pesan Nabi dimaksudkan untuk mempercepat proses perjalanan saja. Sementara sebahagian yang lain baru melakukan shalat 'Ashar setelah sampai di tempat tujuan, sebagaimana yang dipesankan oleh Nabi SAW. ${ }^{1}$

${ }^{1}$ Hadits yang menjelaskan hal tersebut adalah :

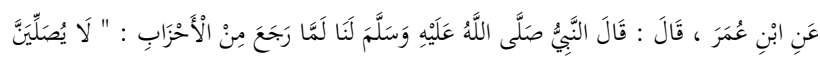

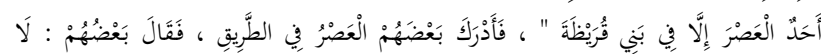

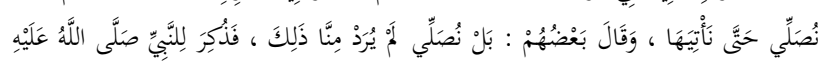

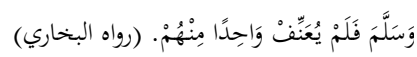

Pada periode formatif sejarah perumusan doktrin Islam, para imam mazhab - dalam batasbatas tertentu - juga telah melakukan kontekstualisasi pemahamaan. Imam Malik (w. 179 H) misalnya, melakukan kontekstualisasi terhadap hadits yang melarang pria melamar wanita yang sedang dalam lamaran pria lain. Menurut Malik, yang dilarang adalah melamar wanita yang cenderung telah menerima lamaran pria itu dan telah ada kesepakatan mengenai maharnya. $^{2}$

Kontekstualisasi hadits yang dimotori oleh dua khalifah di atas tentu saja menimbulkan kontroversi. 'Umar mendapat tantangan keras dalam musyawarah yang dilakukan berulang kali oleh sahabat-sahabat senior dan membutuhkan waktu berbulan-bulan untuk meyakinkan perlunya dilakukan modifikasi sistem pembagian harta rampasan perang demi keadilan. Reaksi yang lebih keras, tampaknya justru diterima oleh 'Usman. Untuk menetapkan hasil kodifikasinya sebagai mushafal-imam, 'Usman memerintahkan untuk membakar mushaf-mushaf pribadi yang dimiliki para sahabatnya. Akibatnya, 'Usman digelari harraq mashahif, sang pembakar mushafmushaf al-Qur'an. ${ }^{3}$

Lamanya waktu yang dibutuhkan 'Umar dan 'Usman menunjukkan bahwa kontekstualisasi hadits yang mereka lakukan menimbulkan kontroversi yang cukup dalam. Hal itu dapat

${ }^{2}$ Muhammad al-Khudari Bik, Tarikh al-Tasyri ‘ al-Islami (Beirut: Dar al-Fikr, 1967), 182.

3'Abd al-'Azim al-Zarqani, Manahil al-'Irfan fi 'Ulum alQur'an (Mesir: Isa' al-Babiy al-Halabiy, t.th), 262. 
dimaklumi, karena otoritas agama dan politik ketika itu tidak hanya berada di tangan satu orang, 'Umar atau 'Usman, tetapi tersebar di antara sahabat-sahabat Nabi terkemuka yang lain. Berbeda dengan pada zaman Nabi saw, di mana otoritas agama dan politik itu hanya di tangan satu orang, yakni Nabi saw. Oleh karena itu, kontekstualisasi hadits dalam skala individual dilakukan oleh sekelompok utusan nabi ke Bani Quraizhah tersebut tidak menimbulkan kontroversi. Dengan otoritasnya, Nabi saw menyelesaikan masalah mereka secara bijaksana dan memuaskan. Kepada utusan yang melaksanakan salat di jalan, Nabi saw mengapresiasinya dengan mengatakan, "Kamu mendapatkan pahala", dan kepada utusan yang melaksanakan salat di perkampungan Bani Quraizah, Nabi saw memuji dengan pernyataannya, "Kamu telah melaksanakan sunnah dengan tepat".

Meskipun menimbulkan kontroversi, apa yang mengiringi kejadian pada masa 'Umar dan 'Usman itu tidak berlangsung lama, paling tidak, tidak diwarisi oleh generasi berikutnya, karena adanya kearifan keagamaan dan rekomendasi Nabi saw untuk menempatkan kebijakan khalifah penggantinya sebagai sunnah yang harus diikuti dan dipegang teguh.

Lain halnya dengan kontroversi yang ditimbulkan oleh kontekstualisasi hadits yang dilakukan Imam Malik (w. 179 H). Kontroversi antara Malik dan Abu Hanifah (w. $150 \mathrm{H}$ ) di satu pihak, dan dengan Imam Syafi' $i$ (w. 204 H) serta golongan Zahiriyah di pihak lain, sebenarnya dapat dikatakan tidak tajam, dalam arti tidak menimbulkan friksi dan sikap saling menghujat. Namun, sayangnya kontroversi itu berlangsung lama dan diwariskan dari generasi ke generasi.

Memasuki era modern, umat Islam mulai bersentuhan dengan perkembangan baru dalam berbagai aspek kehidupan, seperti rasionalisme, nasionalisme, dan perubahan sosial budaya. Anomali semakin terasa ketika umat Islam memasuki era globaliasasi dan informasi yang membawa berbagai gagasan seperti demokrasi, pluralisme, dan HAM. Dalam lingkungan masyarakat global ini, umat Islam tidak bisa lagi hidup eksklusif, monolitis, dan diskriminatif. Ajaran Sunnah dalam hadits yang dibangun atas dasar epistemologi era klasik (teosentris, negara teologis, homogen, eksklusif) tentu banyak menghadapi persoalan ketika dihadapkan pada kasus atau gagasan baru yang dibangun atas dasar epistemologi modern. Apalagi saat pemikiran tersebut lebih didominasi pola pikir pragmatis yang tegak di atas fondasi positivisme yang anti metafisis. Di sini nilai-nilai ajaran Sunnah ditantang untuk memberikan solusi yang logisrasional namun tetap orisinal, sehingga Islam tidak dituding sebagai agama yang mengajarkan kekerasan, terror, dan diskriminatif.

Aspek penting dalam pemahaman fiqh yang selalu mendapat perhatian sampai saat sekarang khususnya dalam kajian gender adalah stagnasi pemikiran terhadap problema seorang istri dalam kodratnya sebagai kaum perempuan, yang dari masa ke masa selalu direduksi hanya untuk kepentingan di luar dirinya. Di saat ideologi gender patriarkhis bertalian dengan kepentingan kapitalisme, perempuan disudutkan pada "peran ganda" yang membebani. Sejauh ini, Islam belum mampu memberikan solusi yang memadai kecuali hanya memberikan legitimasi teologis terhadap upaya-upaya domestifikasi yang tidak selamanya menyelamatkan perempuan dari kesewenangwenangan laki-laki ${ }^{4}$

Fiqh perempuan yang merupakan produk penafsiran teks keagamaan, banyak mengandung bias hegemoni laki-laki. Sehingga perwajahan fiqh perempuan menggoreskan garis penindasan dan perampasan hak-hak perempuan. Jika ditarik benang merah dengan apa yang telah dilakukan fiqh perempuan yang telah menjadi milik lakilaki perlu dikaji ulang (reinterpretasi) sehingga

${ }^{4}$ Siti Ruhaini, dalam M. Hajar Dewantoro dan Asnawi (ed.), Rekonstruksi Fiqh Perempuan (Jakarta: Ababil, 1996), 84. 
benar-benar mencerminkan semangat keadilan Islam.

Dalam upaya reinterpretasi fiqh perempuan ini, Budhi Munawar-Rachman menyampaikan tiga kata kunci yang sangat penting, yaitu representasi (dari Lyotard), dekonstruksi (dari Jacques Derrida), dan keterkaitan pengetahuan dan kekuasaan (dari Michel Foucault). ${ }^{5}$

Alat lain yang dapat membantu mereinterpretasi fiqh khususnya pada fiqh perempuan, Munawar-Rachman menambahkan adalah dengan analisis gender. Perspektif analisis gender ini dalam disiplin keilmuan sosiologi yang lebih luas disebut feminisme. Kesadaran feminislah yang justru sekarang ini diperlukan untuk melakukan upaya reinterpretasi fiqh perempuan. ${ }^{6}$

Pisau analisis gender juga ditawarkan oleh Mansour Faqih untuk memahami dan menganalisis tentang apa yang adil dan apa yang tidak adil serta bagaimana mekanisme ketidakadilan menjadi dasar agama. Dengan begitu, pamahaman atau penafsiran terhadap ajaran keadilan prinsip dasar agama akan berkembang sesuai dengan pemahaman atas realitas sosial, karena sesungguhnya prinsip dasar seruan agama Islam (baca: Syariat atau hukum Islam) untuk menegakkan keadilan akan tetap relevan.

Banyak pilihan dilakukan dalam memahami Sunnah, seperti reinterpretasi, takwil, dan tekstual. Metode Re-interpretasi (secara jujur mengakui dan memahami situasi dan kondisi zaman Nabi saw apa adanya, sebagai ijtihadnya, bisa benar dan salah), setelah dilihat dari berbagai ilmu soosial dan budaya terhadap konteks waktu itu, maka zaman sekarang dapat diamalkan jika sesuai dan boleh tidak jika tidak sesuai.

Mereinterpretasi pemahaman terhadap hadits-hadits "yang memandang rendah

${ }^{5}$ Budhy Munawar Rachman, dalam M. Hajar Dewantoro dan Asnawi (ed.), Rekonstruksi Fiqh Perempuan (Jakarta: Ababil, 1996), 18.

${ }^{6}$ Ibid., 14. perempuan" merupakan suatu keniscayaan, karena proses "peremehan" itu telah berlangsung lama dan mengendap dalam keyakinan umat Islam. Proses semacam itu seringkali bersentuhan dengan interpretasi agama yang dilestarikan oleh politik kepentingan laki-laki yang memproduksi kekuasaan. Meskipun menurut Foucault, kekuasaan itu selalu memperoleh lawan tanding, namun seringkali tidak sebanding, apalagi jika relasi kekuasaan yang terbangun itu mendapatkan dukungan dari otoritas agama. Oleh karena itu, diperlukan beragam cara untuk memutuskan relasi kuasa yang menindas tersebut. Salah satu jalan yang cukup penting untuk dipilih adalah dengan melakukan reinterpretasi pemahaman terhadap hadits-hadits gender yang hasilnya nanti dipublikasikan kepada masyarakat secara luas.

Hadits-hadits yang berbicara tentang gender sangat banyak, maka dalam tulisan ini pembahasannya akan difokuskan kepada dua hadits saja, yaitu hadits tentang perempuan kurang akal dan agama, dan hadits tentang perempuan menjadi pemimpin. Pemilihan kedua hadits tersebut didasarkan pada banyaknya perdebatan dan perbedaan yang terjadi di tengahtengah masyarakat tentang maksud dan makna hadits-hadits tersebut, demikian juga kedua hadits di atas bersentuhan langsung dengan kehidupan perempuan. Dalam pembahasannya akan difokuskan pada penjelasan kualitas hadits dan mencari konteks sosial, politik, ideologi, dan budaya secara timbal balik yang mempengaruhi dalam pemaknaan hadits-hadits tersebut, serta pengaruh mereinterpretasi pemahaman haditshadits nabi tersebut terhadap pelaksanaan hukum tentang hak dan kewajiban perempuan.

\section{Hadits tentang Perempuan Kurang Akal dan Agama}

Menurut informasi Mu'jam Mufahras li alfaz al-Hadits, hadits yang menjelaskan tentang perempuan kurang akal dan agama diriwayatkan oleh Imam Bukhari dalam Shaheh-nya pada kitab haid bab yang ke-16, kitab zakat bab yang 
ke-44; Imam Muslim dalam Shahehnya pada kitab iman, hadits yang ke- 122; Imam Abu Daud pada kitab sunnah bab yang ke-15; Imam alTirmidzi pada kitab Iman bab yang ke-6; Ibn Majah pada kitab fitan bab yang ke-19; dan Imam Ahmad bin Hanbal dalam kitabnya juz II, hal. 67, 372, 374. ${ }^{7}$ Hadits tersebut berbunyi:

$$
\begin{aligned}
& \text { حدثنا سعيد بن أبي مريم قال أخبرنا محمد بن جعفر قال }
\end{aligned}
$$

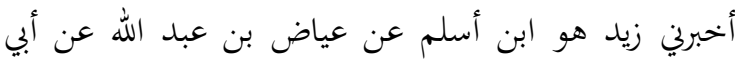

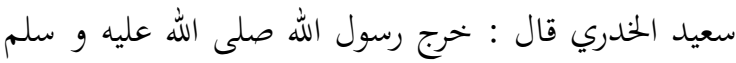

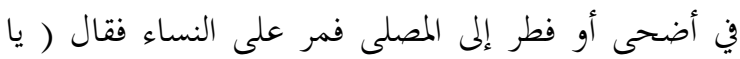

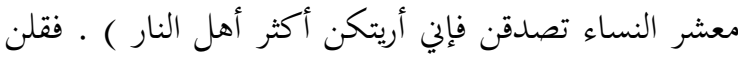

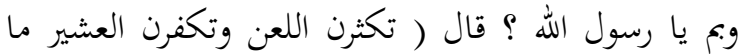

$$
\begin{aligned}
& \text { رأيت من ناقصات عقل ودين أذهب للب الرجل الحازم من لـ لهن } \\
& \text { إحداكن ) . قلن وما نقصان ديننا وعقلنا يا رسول الله ؟ } \\
& \text { قال (أليس شهادة المرأة مثل نصف شهادة الرجل). قلن بلى لى }
\end{aligned}
$$

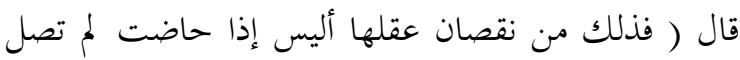

$$
\begin{aligned}
& \text { ولم تصم) .قلن بلى قال (فذلك من نقصان دينها). (رواه }
\end{aligned}
$$

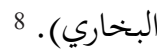

Sa'id bin Abi Maryam menceritakan kepada kami, ia berkata Muhammad bin Ja'far menceritakan kepada kami, ia berkata Zaid (anak Aslam) menceritakan kepada kami dari 'Iyadh bin 'Abdillah dari Abi Sa'id alHudriy ia berkata: Rasulullah SAW keluar di hari raya 'idil Adhha atau 'Idil Fitri menuju Mushalla, maka ia melewati sekelompok perempuan, lalu berkata; (Hai sekalian perempuan bershadaqahlah kalian, sesungguhnya aku melihat kalian banyak di dalam neraka. Mereka lalu bertanya; Kenapa ya Rasulullah?, Rasulullah SAW menjawab; (kamu banyak menyebarkan laknat dan banyak yang durhaka pada suaminya, saya juga melihat pada kalian berupa kekurangankekurangan, yaitu kurang akal dan kurang agama. Di antara salah satu kalian yang dapat meluluhkan hati seorang laki-laki yang teguh hatinya). Lalu kami bertanya lagi, apa yang dimaksud dengan kurang akal dan kurang agama itu ya Rasulullah?. Rasul menjawab (apakah kamu tidak melihat bahwa saksi perempuan itu separoh dari saksi lakilaki). Mereka menjawab; benar, lalu Rasul berkata (itu adalah bentuk kekurangan akalnya, kemudian apakah kalian tidak melihat bahwa apabila kalian haid kalian tidak shalat dan tidak puasa?. Mereka menjawab; benar, Rasul bersabda itu adalah bentuk kekurangan agamanya) (HR. Bukhari).

Bila dilihat dari masing-masing periwayat, maka jalur sanad hadits di atas adalah sebagai berikut:

\footnotetext{
${ }^{7}$ Muhammad Fu'ad Abdul Baqiy, al-Mu'jam al-Mufahras li al-Fazh al-Hadits al-Nabawiy, jilid, VI (Beirut: Mathba'ah, t.th), 539.

${ }^{8} \mathrm{Abu}$ Abdillah Muhammad bin Ismail al-Bukhari (selanjutnya ditulis al-Bukhari), al-Jami' al-Shaheh, juz I (t.tp: al-Bathba'ah al-Salafiyah, 1400 H), 64.
} 


\section{Jalur Sanad Hadits}

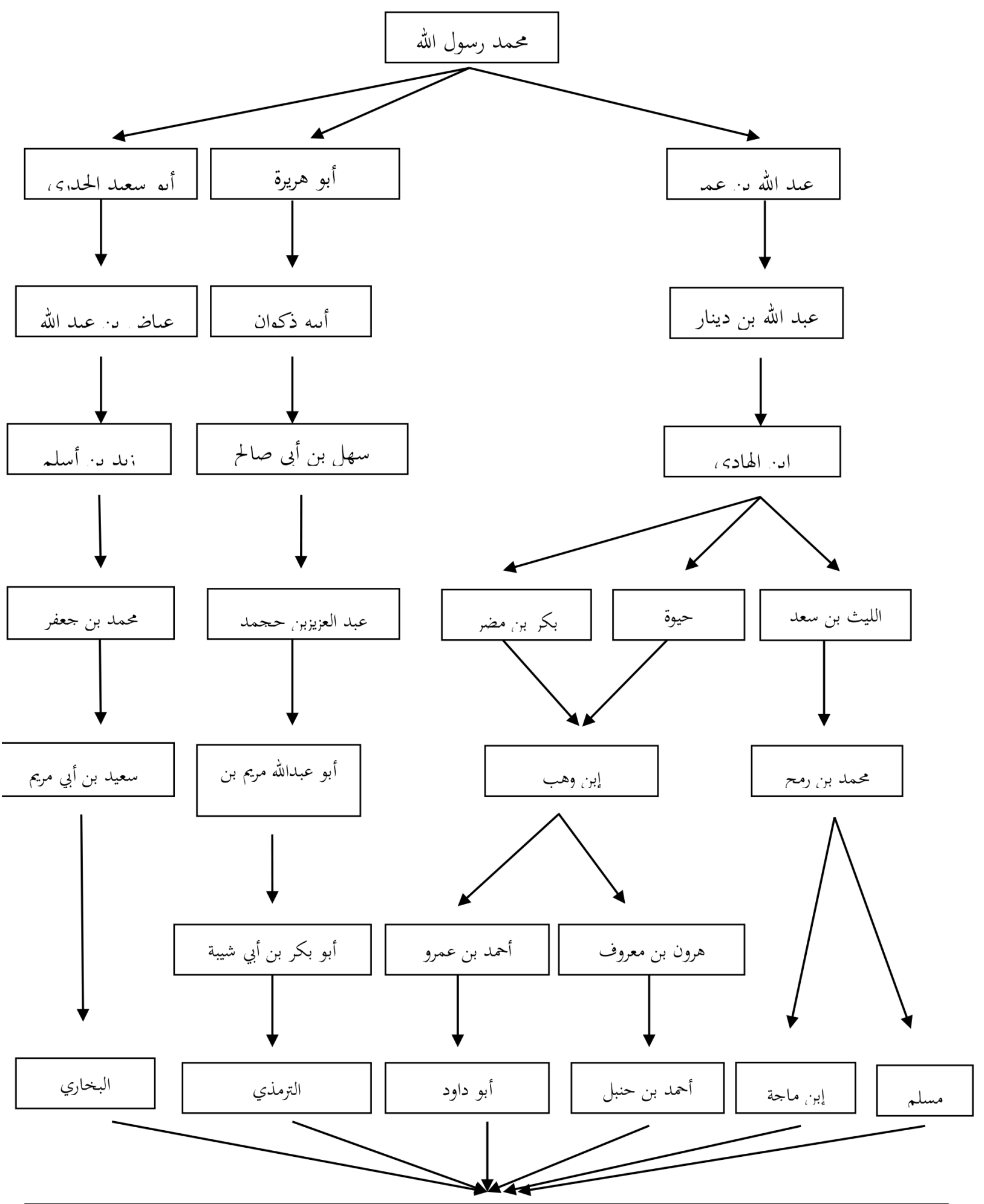

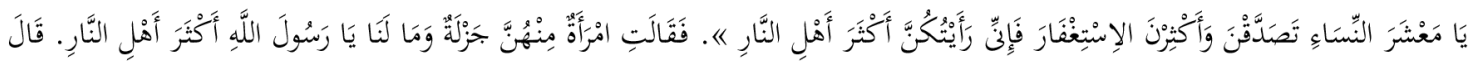

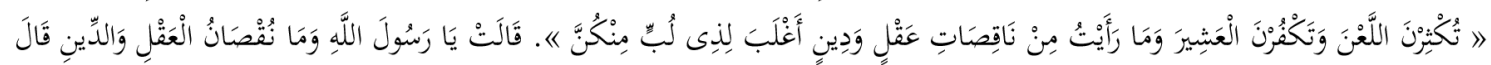

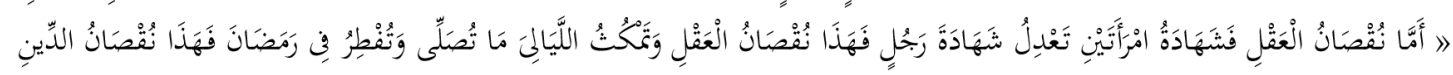


Dengan memperhatikan setiap rangkaian masing-masing sanad hadits di atas, baik melalui jalur al-Bukhari, Muslim, Abu Daud, Ibn Majah, dan Ahmad bin Hanbal, dilihat dari masa hidup, ataupun penjelasan dari masing-masing sanad bahwa mereka terbukti saling memberi dan menerima riwayat, begitupun dilihat dari komentar yang diberikan oleh kritikus hadits terhadap mereka, maka dapat disimpulkan bahwa hadits melalui imam mukharrij tersebut di atas, sanadnya muttasil, dan semua sanadnya 'adil, maka kualitas hadits tersebut adalah shaheh dan dapat dijadikan hujjah. Sedangkan melalui jalur Imam al-Tirmidzi, hadits di atas berstatus hasan, karena ada salah seorang sanadnya, yaitu Abdul Aziz bin Muhammad yang termasuk ke dalam sanad yang kurang bagus hafalannnya (sayyi' alhifzhi).

Dalam teks hadits di atas terdapat kata ناقِصَّات itu bentuk plural dari kata ناقص Kata ناقص berasal dari akar kata نقص, ينقص, نقصا yang berarti: kurang atau yang tidak sempurna. ${ }^{9}$ Dalam bahasa Indonesia, kurang adalah tidak atau belum sama dengan yang seharusnya. Kurang akal berarti: tidak berapa pandai, agak gila. Sedangkan kurang agama berarti: kurang keyakinan, mudah tergoda, dan mudah tergiur. ${ }^{10}$

Mengacu kepada makna kata di atas, maka dapat dipahami bahwa wanita itu tidak berapa pandai dan kurang keyakinannya serta mudah tergoda. Kalau pengertian secara tekstual ini diterima berarti kedudukan wanita tidak sama dengan laki-laki di sisi Allah SWT. Padahal Allah SWT sendiri menyebutkan dalam beberapa ayat-Nya bahwa kedudukan laki-laki dan wanita sama di sisi Allah, seperti ayat-ayat berikut:

${ }^{9}$ Butras al-Bustaniy, Qutr al-Muhit, Juz II (t.tp: t.p, t.th.), 2223.

${ }^{10}$ Depdikbud, Kamus Besar Bahasa Indonesia (Jakarta: Balai Pustaka, 1998), 478. a. Surat al-Hujurat ayat 13 sebagai berikut:

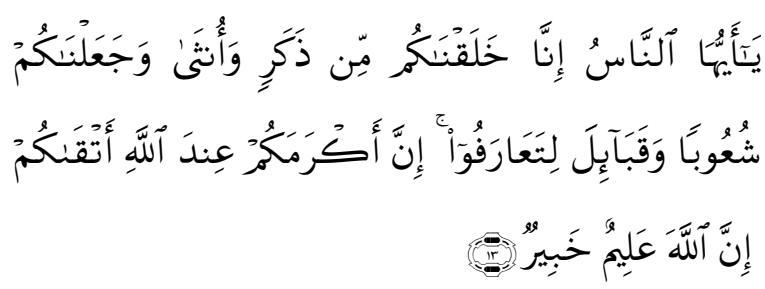

Artinya: Hai manusia sesungguhnya Kami menciptakan kamu dari seorang laki-laki dan seorang perempuan, dan menjadikan kamu berbangsa-bangsa dan bersukusuku supaya kamu saling kenal mengenal. Sesungguhnya orang yang paling mulia di antara kamu di sisi Allah ialah orang yang paling bertakwa di antara kamu. Sesungguhnya Allah Maha Mengetahui lagi Maha Mengenal.

b. Surat al-Nisa' ayat 124 sebagai berikut:

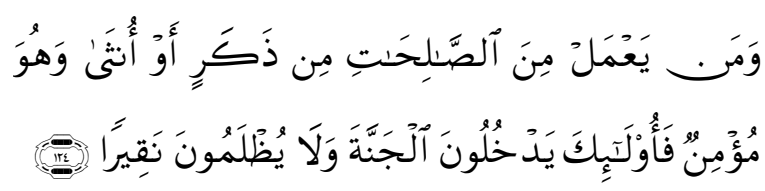

Artinya: Barangsiapa yang mengerjakan amal-amal saleh, baik laki-laki maupun perempuan, sedangkan ia orang yang beriman, maka mereka itu masuk ke dalam surga dan mereka tidak dianiaya walau sedikitpun.

c. Surat al-Taubah ayat 71 sebagai berikut:

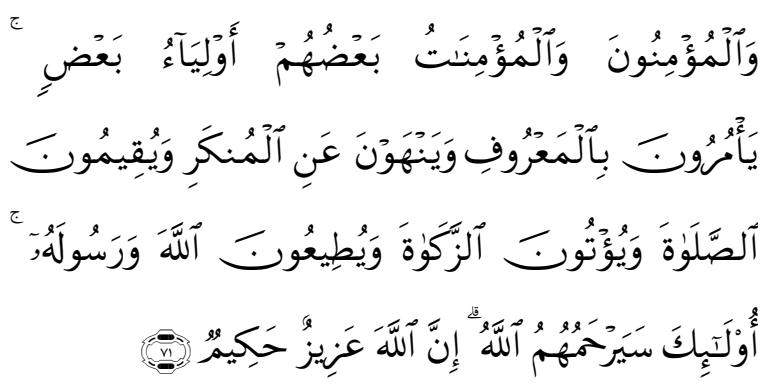

Artinya: Dan orang-orang yang beriman, laki-laki dan perempuan, sebahagian mereka (adalah) menjadi penolong bagi sebahagian yang lain. Mereka menyuruh (mengerjakan) yang ma'ruf, mencegah 
dari yang munkar, mendirikan shalat, menunaikan zakat dan mereka taat pada Allah dan Rasul-Nya. mereka itu akan diberi rahmat oleh Allah; Sesungguhnya Allah Maha Perkasa lagi Maha Bijaksana.

Ketiga ayat di atas tidak ada satupun yang menyatakan bahwa perempuan itu derajatnya di bawah laki-laki, akan tetapi mereka dipandang sama di sisi Allah SWT. Al-Qur'an meninggikan derajat kaum wanita, scperti ibu Nabi Musa AS, ibu Nabi Isa AS, istri-istri Nabi Muhammad SAW (umm al-mu'minin). Al-Qur'an juga menyebut seorang penguasa wanita, seperti Ratu Saba' yang memimpin kaumnya dengan penuh kebijaksanaan, dan banyak lagi contoh lain yang menjelaskan bahwa wanita itu tidak kurang akal.

Hadits yang menerangkan tentang wanita kurang akal dan agama harus dilihat dari kasus yang terjadi ketika hadits itu diucapkan oleh Rasulullah SAW. Peristiwa yang menyebabkan hadits itu muncul adalah berdasarkan riwayat dari Abdullah ibn Umar di atas, ia mengatakan bahwa Rasulullah SAW keluar untuk melaksanakan salat 'id al-adha (Hari Raya Kurban), ia berjalan melewati kaum wanita, lalu ia berkata: Wahai kaum wanita bersedekahlah dan banyaklah beristighfar (minta ampun), karena aku melihat kebanyakan isi neraka itu adalah kaum wanita. Salah seorang di antara wanita itu bertanya: Ya Rasulullah, apakah kesalahan kami, sehingga kami banyak penghuni neraka? Rasulullah SAW menjawab: Karena kaum wanita suka mengeluh, dan melupakan jasa-jasa suami. Kemudian ia bersabda lagi: Aku tidak melihat orang yang kurang akal dan kurang agama yang melebihi kamu sekalian. Wanita itu melanjutkan pertanyaannya: Apakah maksud kami kurang akal dan kurang agama? Rasulullah SAW menjawab: Kurang akal maksudnya adalah karena kesaksian dua orang wanita sama dengan kesaksian satu orang pria. Adapun maksud kurang agama adalah wanita tidak bisa salat dan puasa beberapa hari pada bulan Ramadan karena haid, itu dinamakan dengan kurang agama. ${ }^{11}$

Memperhatikan asbab al-wurud hadits di atas, dapat disimpulkan bahwa hadits tersebut tidak bermakna hakiki, tetapi majazi. Artinya, wanita itu bukanlah orang yang kurang pintar dan bukan pula orang yang kurang keyakinan beragamanya, sebab sejarah membuktikan banyak wanita yang pintar dan banyak pula yang kuat imannya. Hadits di atas dapat dinterpretasikan sebagai rasa ketakjuban Rasulullah SAW kepada wanita atas semangat mereka yang kuat dalam mensiarkan agama Allah SWT.

Kurang akal ditafsirkan dengan kesaksian dua orang wanita sama dengan kesaksian satu orang laki-laki, karena berdasarkan petunjuk alQur'an yang mengatakan bahwa wanita itu pelupa, dan dengan adanya scorang wanita lain di sisinya, maka kedua-duanya dapat saling mengingatkan dan menjelaskan tentang sesuatu secara sempurna. Pernyataan al-Qur'an surat alBaqarah ayat 282 sebagai berikut:

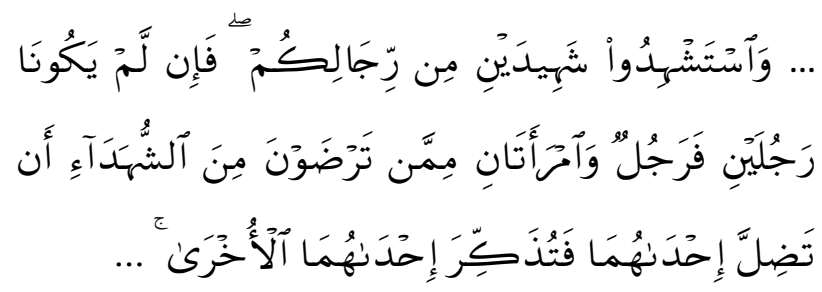

Artinya: Dan persaksikanlah dengan dua orang saksi dari orang laki-laki di antaramu. Jika tidak ada dua orang laki-laki, maka (boleh) seorang laki-laki dan dua orang perempuan dari saksi-saksi yang kamu ridhai, supaya jika seorang lupa, maka seorang lagi mengingatkannya.

Muhammad al-Ghazali pernah melakukan penelitian tentang wanita yang sedang menstruasi. Hasil penelitiannya itu menunjukkan bahwa wanita pada masa menstruasi hampir-hampir menyerupai seorang yang sedang menderita sakit.

\footnotetext{
${ }^{11}$ Ibrahim ibn Muhammd ibn Kamal al-Din al-Dimasyqiy, al-Bayan wa al-Ta'rif Asbab Wurud al-Hadits al-Syarif, Juz III (Beirut: Daar al-Saqafah, t.th.), 349.
} 
Pembahan-perubahan yang dialaminya dalam perasaan maupun pada sebagian organ tubuhnya, menyebabkan mudah dilanda kebingungan dan keraguan dalam berpikir atau bertindak. Sedangkan kemantapan dalam memberikan kesaksian merupakan suatu keharusan.

Pernyataan di atas menunjukkan bahwa wanita itu bukannya kurang akal (tidak pintar), tetapi yaag dimaksud adalah bahwa wanita itu pelupa. Untuk itu, perlu ada orang yang membantu mengingatkannya agar persoalan yang dihadapkan kepadanya menjadi jelas dan tuntas.

\section{Perempuan Menjadi Pemimpin}

Menurut informasi Mu'jam Mufahras li alfaz al-Hadits, hadits yang menjelaskan tentang perempuan menjadi pemimipin diriwayatkan oleh Imam Bukhari dalam Shaheh-nya pada kitab maghazi bab yang ke-82, dan kitab fitan bab yang ke-18; Imam al-Tirmidzi dalam Sunan-nya pada kitab Fitan hadits yang ke- 75; Imam al-Nasa'i pada kitab qadha' bab yang ke-8; dan Imam Ahmad bin Hanbal dalam kitabnya juz V, hal. $38,43,47,51 .^{12}$

${ }^{12}$ Fu'ad Muhammad Fu'ad Abdul Baqiy, jilid V, 196.

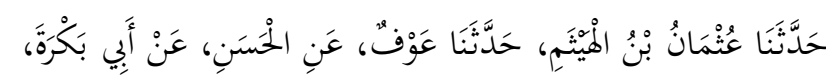

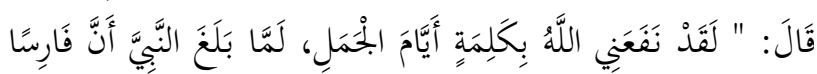

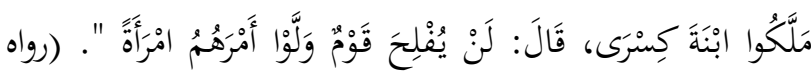
البخاري).

Artinya: Dari Utsman bin Haitsam dari Auf dari Hasan dari Abi Bakrah berkata: Allah memberikan manfaat kepadaku dengan sebuah kalimat yang aku dengar dari Rasulullah SAW pada hari perang jamal, setelah aku hampir membenarkan mereka (Ashabul Jamal) dan berperang bersama mereka, ketika sampai kabar kepada Rasulullah SAW bahwa bangsa Persia mengangkat putri Kisra sebagai pemimpin, beliau bersabda: Tidak akan beruntung suatu kaum yang menyerahkan urusan (pemerintahan) mereka kepada seorang wanita (HR. Al-Bukhari).

Bila dilihat dari masing-masing periwayat, maka jalur sanad hadits di atas adalah sebagai berikut:

${ }^{13}$ Al-Bukhari, Juz VI , 2600. 


\section{Jalur Sanad Hadits}

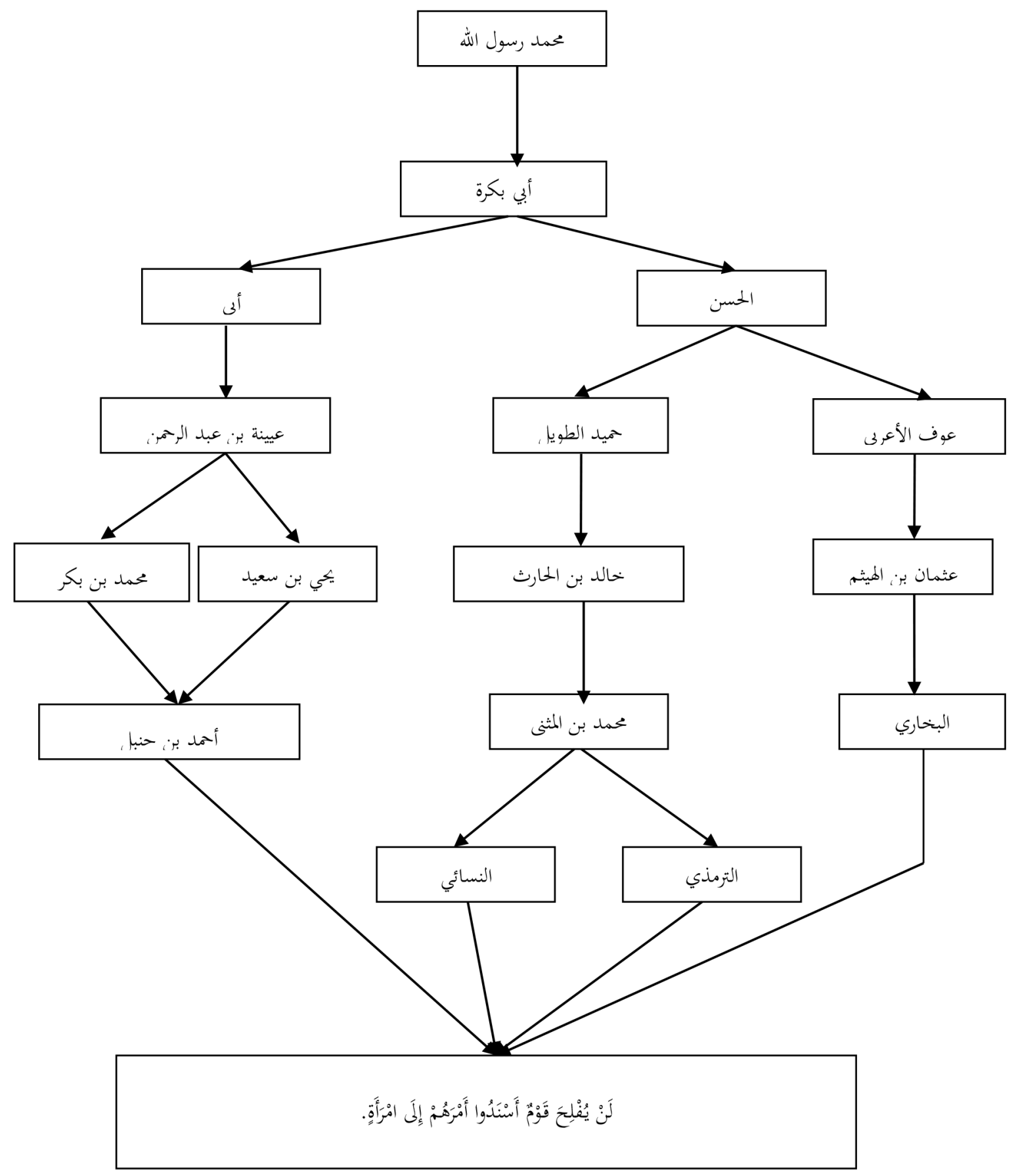

Dengan memperhatikan setiap rangkaian masing-masing sanad hadits di atas, baik melalui jalur al-Bukhari, al-Tirmidzi, al-Nasa'iy, dan Ahmad bin Hanbal, dilihat dari masa hidup, ataupun penjelasan dari masing-masing sanad bahwa mereka terbukti saling memberi dan menerima riwayat, begitupun dilihat dari komentar yang diberikan oleh kritikus hadits terhadap mereka. Maka dapat disimpulkan bahwa hadits melalui mukharrij tersebut di atas, sanadnya muttasil, dan semua sanadnya 'adil, maka kualitas hadits tersebut adalah shaheh dan dapat dijadikan hujjah.

Sepintas lalu dalam hadits tersebut terlihat 
tidak ada permasalahan. Tapi bila direnungkan sejenak, lalu diperhatikan fakta-fakta sejarah di mana banyak wanita yang berhasil memimpin negara, maka terasa hadits itu kurang tepat karena tidak didukung oleh fakta. Apalagi jika hal itu dihadapkan dengan ayat-ayat al-Qur'an yang menginformasikan tentang keberhasilan wanita seperti Ratu Bilqis memimpin negeri Saba' di Yaman pada masa Nabi (Raja) Sulaiman AS. sebagaimana terdapat dalam Surah an-Naml ayat 22-24. Di dalam ayat-ayat itu Tuhan menjelaskan kesuksesan gemilang yang dicapai Ratu Bilqis dalam memimpin negeri Saba'. Negeri mereka aman dan makmur, rakyat rukun dan damai, serta mempunyai kekuatan militer yang tangguh. Kemudian ia masuk Islam bersama rakyatnya dan tunduk di bawah pemerintahan raja Sulaiman.

Dalam sejarah peradaban Islam, tercatat Shajarat al-Durr pendiri kerajaan Mamluk yang memerintah wilayah Afrika Utara terus ke Asia Barat $\left(1250\right.$ - 1257 M). ${ }^{14}$ Demikian pula Ratu Elizabeth II dari Inggris, sampai sekarang masih bertahan setelah memerintah lebih dari empat dasawarsa. ${ }^{15}$ Sebelumnya juga memerintah Ratu Elizabet I dari tahun $1533-1603$ M. ${ }^{16}$

Permasalahan yang timbul ketika memahami hadits di atas ketika melihat terjemahan yang dibuat oleh sebahagian penterjemah hadits. Timbulnya terjemahan yang kurang tepat terhadap hadits itu sebagaimana dikutip di atas agaknya karena penerjemahnya terpengaruh oleh latar belakang (asbab al-wurud) munculnya hadits tersebut yang menurut al-Siba'i ialah ketika Abarwiz [putri raja] dari Persia menjadi kepala negara menggantikan ayahnya yang meninggal dunia; ${ }^{17}$ tetapi sayang

\footnotetext{
${ }^{14}$ Philif K. Hitti, History of the Arabs, cet. ke-10 (London: The Macmillan Press Ltd, 1974), 671-673.

${ }^{15}$ Harian Kompas, "Tajuk Rencana”, Jakarta 23 Desember 1995.

${ }^{16}$ Hasan Sadiliy, Ensiklopedi Indonesia, Buku 2 (Jakarta, Ichtiar Baru-Van Hoeve, 1980), 917.

${ }^{17}$ Musthafa al-Siba'i, Wanita di antara Hukum Islam dan Perundang-undangan, terj. Chadijah Nasution, cet. ke-3 (Jakarta, Bulan Bintang, 1977), 61.
}

terjemahan itu kurang didukung oleh fakta sejarah yang empiris dan ayat-ayat al-Qur'an sebagaimana telah dijelaskan di atas. Terjemahan yang demikian dapat menimbulkan anggapan negatif terhadap hadits Nabi, sebab terjemahan serupa itu memberikan pemahaman yang kontradiktif antara hadits Nabi di satu pihak dan realitas sosial kehidupan umat manusia di pihak lain; padahal pemahaman serupa itu tak perlu terjadi jika terjemahannya memperhatikan kondisi yang hidup di tengah masyarakat umat manusia, dan tidak perlu terpengaruh oleh latar belakang hadits tersebut, karena dijadikan tolok ukur dalam mengambil suatu keputusan (istinbath al-hukm) menurut mayoritas ulama ialah umum lafal bukan khusus sebab (al- ibrat bi 'umum al-lafazh la bi khusush al-sabab). ${ }^{18}$

Berangkat dari kaidah itu maka kita dapat berkata, meskipun latar belakang hadits itu muncul dari kasus naiknya wanita jadi kepala negara di Persia, namun lafal yang dipakainya umum tidak membicarakan secara khusus tentang kepala negara. Kata قوم dan di dalam hadits itu misalnya, adalah lafal nakirah (indefinite). Itu berarti lafal 'kaum' dan mar'ah tersebut berkonotasi 'kaum' dan 'wanita' mana saja dan di mana saja, tidak khusus untuk orang Persia. Demikian pula kata أمرهم di dalam hadits itu, berkonotasi umum, tidak khusus tentang urusan pemerintahan, tapi mencakup semua urusan yang berhubungan dengan bangsa atau orang yang dipimpin. Keumuman itu tampak dari pemakaian lafal mufrad (tunggal): أمر, yang di-idhafat-kan (ditambahkan) kepada lafal sesudahnya هم Menurut kaidah ushul fiqh, kata tunggal bila diidhafat-kan kepada isim ma' rifat (kata benda yang jelas atau definite), maka ia mengandung konotasi umum. ${ }^{19}$

\footnotetext{
${ }^{18}$ Muhammad Abdul Qadir al-Arusi, Masalah takhshish al'Am bi al-Sabab (t.tp: t.p, 1983), 9.

${ }^{19}$ Syamsuddin al-Mahalli, dalam Hasyiyah al- 'Allamah alBunnani (t.tp: 'Isa al-bab al-Halabi, t. th), 413.
} 
Contoh lain misalnya lafal أمره yang terdapat di dalam ayat 82 dari surat Yasin:

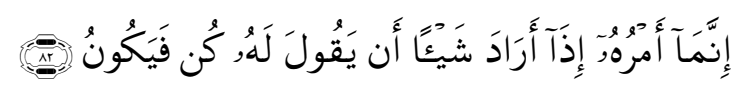

Artinya: Sesungguhnya semua urusan-Nya (Allah) apabila Dia menghendaki sesuatu. Ia berkata padanya "jadilah kamu”, maka jadilah apa yang dikehendaki-Nya itu.

Contoh lain misalnya أمر فرعون di dalam ayat

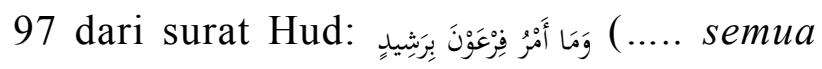
urusan Fir'aun itu tidak ada yang baik).

Setelah memperhatikan pemahaman ayat-ayat al-Qur'an dan kaedah itu kemudian diterapkan pada hadits Nabi tadi, maka dapat disimpulkan bahwa yang dimaksud Nabi dengan hadits itu ialah "suatu bangsa tidak pernah memperoleh sukses jika semua urusan bangsa itu diserahkan [sepenuhnya pada kebijakan] wanita sendiri [tanpa melibatkan kaum pria]", jadi semua urusan pemerintahan itu ditangani oleh wanita sendiri, tanpa ada laki-laki yang diikutsertakan di dalamnya, mulai dari jabatan tertinggi sampai terendah, bahkan satpam (satuan pengaman) dan tukang sapu pun ditangani oleh wanita. Jika demikian halnya, maka sangat masuk akal mereka tidak akan beruntung karena mereka mempunyai keterbatasan-keterbatasan manusiawi, baik secara fisik maupun psikis.

Dari pemahaman hadits sebagaimana dikemukakan itu jelas bagi kita bahwa pendapat yang mengatakan, bahwa wanita tidak boleh menjadi kepala negara karena tidak akan beruntung atau sukses dalam memimpin, kurang didukung oleh fakta sejarah dan argumen yang kuat, karena hadits tersebut tidak menegaskan hal itu secara ekspilit.

\section{Kesimpulan}

Penelitian terhadap keshahehan sanad dan matan yang dilakukan terhadap hadits-hadits yang berkaitan dengan gender ini, pada dasarnya termasuk ke dalam kategori hadits maqbul dalam status shaheh dan hasan, sehingga dapat dijadikan hujjah dalam kehidupan beragama, hal ini berdasarkan pada hasil penelitian terhadap sanad yang terdapat pada hadits tersebut yang bersifat 'adil dan dhabit, serta terhindar dari syaz dan 'illat (cacat). Begitu pula dengan matan yang dimiliki oleh setiap hadits tersebut, juga sudah memenuhi kriteria matan yang shaheh.

Reinterpretasi yang dilakukan kepada kedua hadits di atas, ternyata dapat menimbulkan pemahaman baru, sehingga berdampak pula terhadap pelaksanaan hukum (fiqh hadits) dari hadits tersebut. Reinterpretasi itu muncul dari dua dimensi analisis, yaitu:

a. Melalui pendekatan linguistik (bahasa), pemahaman melalui pendekatan ini memberikan pemahaman yang baru terhadap hadits-hadits yang dibahas, khususnya hadits yang berkaitan tentang perempuan menjadi pemimpin, yang mana ketidakberhasilan kepemimpinan perempuan itu bukan disebabkan oleh ketidakpintaran perempuan, namun terletak pada manajemennya, yang apabila semua urusannya diserahkan kepada perempuan tanpa melibatkan kaum laki-laki.

b. Reinterpretasi dilakukan melalui pendekatan sosial kemasyarakatan dengan melihat kepada dilalah bahasa yang terdapat dalam teks. Pemahaman ini dapat dilihat dari pemahaman hadits tentang wanita kurang akal dan agama. Kurang akal diinterpretasikan dengan pelupa, dan ini merupakan sifat manusia secara keseluruhan. Sedangkan kurang agama bukan berarti kurang keyakinan, atau kurang kepercayaan, akan tetapi kurang agama diinterpretasikan dengan sifat khusus yang dimiliki oleh wanita tersebut, yaitu adanya menstruasi (haid) yang dialaminya setiap bulan yang mengakibatkan mereka tidak dapat melaksanakan ibadah secara utuh.

Dengan memperhatikan reinterpretasi yang dilakukan pada kedua hadits di atas, maka ahl ra'yi kiranya memberikan solusi yang dapat menjadi jembatan untuk menghubungkan antara pemahaman salaf dengan pemahanan khalaf yang ada pada saat sekarang ini. 


\section{Daftar Kepustakaan}

Abdullah Muhammad Nipan. Membahagiakan Suami Sejak Malam Pertama. Yogyakarta: Mitra Pustaka, 2000.

al-Adabi, Salahuddin bin Ahmad. Manhaj Naqd al-Matn. Beirut: Daar al-'Afaq al-Jadidah, 1983.

al-Arusi, Muhammad Abdul Qadir. Masalah takhshish al-'Am bi al-Sabab. T.tp., t.p, 1983.

al-Ashqalaniy, Ibn Hajar. Fath al-Bari bi Syarh al-Bukhariy. Mesir: Mustafa al-Babi alHalabi wa Auladuh, 1969.

Baqiy, Muhammad Fu'ad Abdul. al-Mu'jam alMufahras li al-Fazh al-Hadits alNabawiy. Jilid VII. Beirut: Mathba'ah, t.th.

Budhy Munawar Rachman. Dalam M. Hajar Dewantoro dan Asnawi (ed.). Rekonstruksi Fiqh Perempuan. Jakarta: Ababil, 1996.

al-Bustaniy, Butras. Qutr al-Muhit. Juz II. T.tp: t.p, t.th.

Depdikbud. Kamus Besar Bahasa Indonesia. Jakarta: Balai Pustaka, 1998.

al-Dimasyqiy, Ibrahim ibn Muhammd ibn Kamal al-Din. al-Bayan wa al-Ta'rif Asbab Wurud al-Hadits al-Syarif. Beirut: Daar alSaqafah, t.th.

al-Ghazali. Ihya' 'Ulum al-Diin. Kairo: Daar alFikr, 1985.

al-Ghazali, Muhammad. al-Sunnah alNabawiyyah Baina ahl al-Fiqh wa ahl alHadits. Kairo: Daar al-Syuruq, 1989.

Hasaballah, Ali. Usul al-Tasyri' al-Islamiy. Mesir: Daar al-Ma'arif, 1964.

Hasan Sadiliy. Ensiklopedi Indonesia. Buku 2. Jakarta: Ichtiar Baru-Van Hoeve, 1980.

Hassan, Riffat. "Isu Kesetaraan Laki-laki Perempuan dalam Tradisi Islam”. Dalam
Fatimah Marnissi dan Riffat Hassan, Setara di Hadapan Allah. Terjemahan Tim LSPPA. Yogyakarta: LSPPA, Yayasan Prakarsa, 1995.

Hitti, Philif K. History of the Arabs. Cet. ke-10. London: The Macmillan Press Ltd, 1974.

M. Abdul Halim Mahmud. Bagaimana Membahagiakan Suami. Solo: Intermedia, 1999.

al-Mahalli, Syamsuddin. Dalam Hasyiyah al'Allamah al-Bunnani. T.tp: 'Isa al-bab alHalabi, t.th.

Masdar F. Mas'udi. Islam dan Hak-hak Refroduksi Perempuan Dialog Fiqh. Bandung: Mizan, 1997.

Muhammad Fauzil Adhim. Mencapai Pernikahan Barokah. Yogyakarta: Mitra Pustaka, 1999.

Munawwir, Ahmad Warson. Kamus alMunawwir. cet. XIV. Surabaya: Pustaka Progressif, 1997.

al-Nasa'iy. Sunan al-Nasa'iy. Jilid III. Mesir: Syirkah maktabah wa Mathba'ah al-Bab al-Halabi, 1964.

al-Nawawiy. Shaheh Muslim bi Syarh alNawawiy. Beirut: Daar al-Fikr, 1972

Nurchalish Majid. Islam Doktrin dan Peradaban. Jakarta: Paramadina, 1996.

Qal'ahji, Muhammad Rawwas dan Hamid Sadiq Qunaibi. Mu'jam Lughah al-Fuqaha'. Beirut: Daar al-Nafais, 1985.

al-Qardhawiy, Yusuf. Kaifa Nata 'ammal ma'a alSunnah al-Nabawiyyah. Edisi Indonesia. Bandung: Karisma, 1993.

al-Qurthubiy, Abu Abdillah Muhammad Ibn Ahmad. al-Jami'li al-Ahkam al-Qur'an. Kairo, Daar al-Katib al-'Arabiy li alTaba'ah wa al-Nasyr, 1967.

al-Sayyid Mayai. 50 Wasiat Rasulullah SAW bagi 
Wanita. Jakarta: Pustaka al-Kautsar, 1999.

al-Siba'i, Musthafa. Wanita di antara Hukum

Islam dan Perundang-undangan. Terjemahan Chadijah Nasution. cet. ke3. Jakarta: Bulan Bintang, 1977.

Siti Ruhaini. Dalam M. Hajar Dewantoro dan Asnawi (ed.). Rekonstruksi Fiqh Perempuan. Jakarta: Ababil, 1996.

al-Suyuthi. Asbab al-Wurud al-Hadits aw alLam'a fi Asbab Wurud al-Hadits. Beirut: Daar al-Kutub al-Islamiyah, 1984.

Syafiq Hasyim. Hal-hal yang tak Terpikirkan tentang Isu-isu Keperempuanan dalam Islam. Bandung: Mizan, 2001.

al-Syathibi, Abu Ishaq. al-Muwafaqat fi Ushul alSyari'ah. T.tp: Daar al-Ma'rifah, t.th.

al-Syaukaniy, Muhammad Ibn 'Ali. Nail al-Autar.
Jilid. V. Mesir: Mustafa al-Babi al-Halabi wa Auladuh, 1961.

Syuhudi Ismail. Metodologi Penelitian Hadits Nabi. Jakarta: Bulan Bintang, 1992.

Hadits Nabi yang Tekstual dan Kontekstual; Telaah Ma'anil Hadits tentang Ajaran Islam yang Universal, Temporal, dan Lokal. Jakarta: Bulan Bintang, 1994.

al-Thahhan, Mahmud. Taisir Mushthalah alHadits. Beirut: Daar al-Saqafah alIslamiyyah, t.th.

Zaitunah Subhan. Tafsir Kebencian; Studi Bias Gender dalam Tafsir al-Qur'an. Yogyakarta: LKiS, 1999.

al-Zarqani, Abd al-'Azim. Manahil al-'Irfan $f i$ 'Ulum al-Qur'an. Mesir: Isa' al-Babiy alHalabiy, t.th. 